\title{
Comparison of Y1 mouse adrenal cell and coagglutination assays for detection of Escherichia coli heat labile enterotoxin
}

\author{
P A CHAPMAN, CHRISTINE M DALY Public Health Laboratory, Northern General Hospital, \\ Sheffield
}

SUMMARY A commercial coagglutination assay (COA; Phadebact LT-ETEC) was compared with a Y1 mouse adrenal cell assay for detecting the heat labile enterotoxin of Escherichia coli. Of four different media evaluated for use with the COA, only one (modified blood agar) gave a positive result with all strains known to produce heat labile enterotoxin. With modified blood agar, the COA detected $74(85 \%)$ of 87 such strains. Eighty six strains negative by cell culture assay were also negative by COA, and one strain positive by COA could not be confirmed by cell culture. The Phadebact LT-ETEC kit provides a simple, sensitive, and economical method for detecting $E$ coli heat labile enterotoxin.

Heat labile enterotoxin-producing strains of Escherichia coli $\left(\mathrm{LT}^{+}\right.$ETEC) are an important cause of diarrhoea in developing countries, and in those who travel from developed to less developed countries. ${ }^{12}$ Though an uncommon cause of diarrhoea in some developed countries, ${ }^{3-5}$ LT $^{+}$ETEC have recently been reported as a common finding in patients with diarrhoea returning to the United Kingdom from popular mediterranean holiday resorts. ${ }^{2}$

The aim of this study was to compare a commercial coagglutination assay (COA) kit (Phadebact ETECLT, Pharmacia LKB Diagnostics) with a simplified Y1 mouse adrenal cell assay ${ }^{6}$ for detecting LT $^{+}$ETEC.

\section{Material and methods}

$E$ coli test strains were those isolated in previous studies $^{26}$ from patients with diarrhoea returning to Sheffield from abroad. Strains had been stored in nutrient broth with $15 \%$ glycerol at $-70^{\circ} \mathrm{C}$ since first isolation. All were retested in the Y1 mouse adrenal cell assay in parallel with the COA. Eighty seven LT positive and 87 LT negative strains were used to compare the two methods.

The simplified Y1 mouse adrenal cell assay was performed as described earlier, ${ }^{6}$ but with substitution

Accepted for publication 2 February 1989 of clindamycin $45 \mu \mathrm{g} / \mathrm{ml}$ for lincomycin $90 \mu \mathrm{g} / \mathrm{ml}$ in the medium used to enhance toxin production.

The initial evaluation of the coagglutination assay was performed using $10 \mathrm{LT}^{+}$ETEC strains isolated from travellers returning from diverse locations; strains produced widely differing amounts of heat labile enterotoxin as determined by cell culture assay. Each strain was grown for 24 hours on four different media: MacConkey agar (Oxoid CM7b), xylose lysine desoxycholate agar (Oxoid CM469), blood agar (Oxoid columbia agar base with horse blood 5\%), and modified blood agar (blood agar with added clindamycin $45 \mu \mathrm{g} / \mathrm{ml}$ and a final pH of 8.0). Five colonies were then suspended in $100 \mu$ l of extraction fluid supplied with the kit, vortex mixed, and incubated at $37^{\circ} \mathrm{C}$ for one hour. Cells and cell debris were then removed by centrifugation at $3000 \mathrm{~g}$ for two minutes. The clear supernate was then used to prepare a series of doubling dilutions from $1 / 2$ to $1 / 32$ in phosphate buffered saline. The neat supernate and dilutions were then used in the test procedure according to the manufacturer's instructions. Positive results were scored as follows: $+++=$ strong agglutination occurring within one minute; $++=$ moderate agglutination occurring within one minute; and $+=$ weak agglutination occurring within two minutes.

The COA was compared with the Y1 mouse adrenal cell assay using $E$ coli strains grown on modified blood agar and processed as above; only the neat supernate was tested. 


\section{Results}

Table 1 shows the results of the initial evaluation of the COA. Because the only medium to give a positive result on all 10 strains was modified blood agar, this was used in the comparison of the assay with the Y1 mouse adrenal cell assay. Table 2 summarises the results obtained. The COA detected $74(85 \%)$ of 87 strains shown to produce heat labile enterotoxin by cell culture assay. Thirteen strains positive by cell culture were negative by the COA. One strain positive by the COA could not be confirmed by cell culture; 86 strains were negative in both assays.

\section{Discussion}

Despite the importance of $\mathrm{LT}^{+} \mathrm{ETEC}$ as a cause of diarrhoea, ${ }^{12}$ their recognition is usually accomplished in only a few diagnostic microbiology laboratories. This may be partly due to difficulties in previously recommended detection methods. ${ }^{67}$

Cell culture assays for heat labile enterotoxin can be simple, economical, and sensitive, but need to be performed in laboratories with specialist cell culture facilities. While the Y1 cell assay is a reliable and sensitive assay, ${ }^{8}$ other cell culture assays, such as the Chinese hamster ovary (CHO) cell assay may be

Table 1 Initial evaluation of coagglutination assay

\begin{tabular}{|c|c|c|c|c|c|c|c|c|}
\hline \multirow[b]{3}{*}{ Isolate (source) } & \multirow[b]{3}{*}{ Toxin titre } & \multicolumn{7}{|c|}{ Coagglutination assay } \\
\hline & & \multirow[b]{2}{*}{ Medium } & \multicolumn{6}{|c|}{ Supernate dilution } \\
\hline & & & Neat & 2 & 4 & 8 & 16 & 32 \\
\hline P163 (Brazil) & $>=2560$ & $\begin{array}{l}\text { MA } \\
\text { XLD } \\
\text { BA } \\
\text { MBA }\end{array}$ & $\begin{array}{l}- \\
++ \\
+++ \\
+++\end{array}$ & $\begin{array}{l}- \\
- \\
+++ \\
+++\end{array}$ & $\begin{array}{l}- \\
- \\
+++ \\
+++\end{array}$ & $\begin{array}{l}- \\
+ \\
+++\end{array}$ & $\begin{array}{l}- \\
- \\
+++\end{array}$ & $\begin{array}{l}- \\
- \\
++\end{array}$ \\
\hline P164 (Egypt) & $>=2560$ & $\begin{array}{l}\text { MA } \\
\text { XLD } \\
\text { BA } \\
\text { MBA }\end{array}$ & $\begin{array}{l}- \\
- \\
\overline{+}+\end{array}$ & $\begin{array}{l}- \\
- \\
-\end{array}$ & $\begin{array}{l}- \\
\overline{-} \\
-\end{array}$ & $\begin{array}{l}- \\
- \\
-\end{array}$ & $\begin{array}{l}- \\
\overline{-} \\
-\end{array}$ & $\begin{array}{l}- \\
- \\
-\end{array}$ \\
\hline P165 (Russia) & 2560 & $\begin{array}{l}\text { MA } \\
\text { XLD } \\
\text { BA } \\
\text { MBA }\end{array}$ & $\begin{array}{l}- \\
- \\
++\end{array}$ & $\begin{array}{l}- \\
- \\
-\end{array}$ & $\begin{array}{l}- \\
- \\
-\end{array}$ & $\begin{array}{l}- \\
\overline{-} \\
-\end{array}$ & $\begin{array}{l}- \\
-\end{array}$ & $\begin{array}{l}- \\
- \\
-\end{array}$ \\
\hline P166 (Tunisia) & 640 & $\begin{array}{l}\text { MA } \\
\text { XLD } \\
\text { BA } \\
\text { MBA }\end{array}$ & $\begin{array}{l}- \\
- \\
+++\end{array}$ & $\begin{array}{l}- \\
\bar{t}+\end{array}$ & $\begin{array}{l}- \\
- \\
-\end{array}$ & $\begin{array}{l}- \\
- \\
-\end{array}$ & $\begin{array}{l}- \\
\overline{-} \\
-\end{array}$ & $\begin{array}{l}- \\
- \\
-\end{array}$ \\
\hline P167 (Spain) & 2560 & $\begin{array}{l}\text { MA } \\
\text { XLD } \\
\text { BA } \\
\text { MBA }\end{array}$ & $\begin{array}{l}- \\
++ \\
+++ \\
+++\end{array}$ & $\begin{array}{l}- \\
++ \\
+++ \\
+++\end{array}$ & $\begin{array}{l}- \\
+ \\
+++ \\
+++\end{array}$ & $\begin{array}{l}- \\
- \\
+++ \\
+++\end{array}$ & $\begin{array}{l}- \\
- \\
+ \\
+\end{array}$ & $\begin{array}{l}- \\
\overline{-}\end{array}$ \\
\hline P168 (Bulgaria) & 1280 & $\begin{array}{l}\text { MA } \\
\text { XLD } \\
\text { BA } \\
\text { MBA }\end{array}$ & $\begin{array}{l}- \\
++ \\
+++ \\
+++\end{array}$ & $\begin{array}{l}- \\
+ \\
++ \\
+++\end{array}$ & $\begin{array}{l}- \\
- \\
-\end{array}$ & $\begin{array}{l}- \\
- \\
-\end{array}$ & $\begin{array}{l}- \\
- \\
-\end{array}$ & $\begin{array}{l}- \\
- \\
-\end{array}$ \\
\hline P169 (India) & 80 & $\begin{array}{l}\text { MA } \\
\text { XLD } \\
\text { BA } \\
\text { MBA }\end{array}$ & $\begin{array}{l}- \\
\bar{t} \\
+\end{array}$ & $\begin{array}{l}- \\
- \\
-\end{array}$ & $\begin{array}{l}- \\
- \\
-\end{array}$ & $\begin{array}{l}- \\
- \\
-\end{array}$ & $\begin{array}{l}- \\
- \\
-\end{array}$ & $\begin{array}{l}- \\
- \\
-\end{array}$ \\
\hline P171 (Pakistan) & 20 & $\begin{array}{l}\text { MA } \\
\text { XLD } \\
\text { BA } \\
\text { MBA }\end{array}$ & $\begin{array}{l}- \\
\overline{-} \\
+\end{array}$ & $\begin{array}{l}- \\
- \\
-\end{array}$ & $\begin{array}{l}- \\
- \\
-\end{array}$ & $\begin{array}{l}- \\
- \\
-\end{array}$ & $\begin{array}{l}- \\
\overline{-} \\
-\end{array}$ & $\begin{array}{l}- \\
\overline{-} \\
-\end{array}$ \\
\hline P174 (Spain) & 640 & $\begin{array}{l}\text { MA } \\
\text { XLD } \\
\text { BA } \\
\text { MBA }\end{array}$ & $\begin{array}{l}- \\
+++ \\
+++\end{array}$ & $\begin{array}{l}- \\
+ \\
+++\end{array}$ & $\begin{array}{l}- \\
\overline{t+}+\end{array}$ & $\begin{array}{l}- \\
\bar{t} \\
+\end{array}$ & $\begin{array}{l}- \\
-\end{array}$ & $\begin{array}{l}- \\
- \\
-\end{array}$ \\
\hline P182 (Portugal) & 40 & $\begin{array}{l}\text { MA } \\
\text { XLD } \\
\text { BA } \\
\text { MBA }\end{array}$ & $\begin{array}{l}- \\
\overline{+} \\
+\end{array}$ & $\begin{array}{l}- \\
\overline{-} \\
-\end{array}$ & $\begin{array}{l}- \\
\overline{-}\end{array}$ & $\begin{array}{l}- \\
\overline{-} \\
-\end{array}$ & $\begin{array}{l}- \\
\overline{-} \\
-\end{array}$ & $\begin{array}{l}- \\
\overline{-} \\
-\end{array}$ \\
\hline
\end{tabular}

MA = MacConkey agar; XLD = xylose lysine desoxycholate agar; BA = blood agar; MBA = modified blood agar. 
Table 2 Comparison of Phadebact ETEC-LT coagglutination and Y1 mouse adrenal assay for detecting $L T^{+}$ETEC

\begin{tabular}{lll}
\hline Cell culture & Coagglutination & Number \\
\hline Positive & Positive & 74 \\
Positive & Negative & 13 \\
Negative & Positive & 1 \\
Negative & Negative & 86 \\
\hline
\end{tabular}

affected by the cytolethal distending toxin of $E$ coli, which may be misinterpreted as having been produced by heat labile enterotoxin. ${ }^{10}$ Heat labile enterotoxin is antigenic and various immunoassays for its detection have been described, ${ }^{11-15}$ but despite the relative ease with which these tests may be performed, they all have one common limitation - all require a high titre of antitoxin to highly purified heat labile enterotoxin. No such antitoxin is available commercially, and its production would almost certainly be beyond the scope of many diagnostic laboratories.

The introduction of a simple commercial kit for detecting heat labile enterotoxin obviates the need for specialist cell culture facilities and puts testing for $\mathrm{LT}^{+}$ETEC within the scope of any diagnostic microbiology laboratory. The kit as it is currently produced by the manufacturer, however, presented several problems. The instructions did not make clear that the whole test procedure should be controlled by inclusion of known $\mathrm{LT}^{+}$ETEC strains in each batch of tests. The instructions also implied, wrongly, that various selective media such as MacConkey and xylose lysine desoxycholate agar may be used directly in the assay. $\mathrm{LT}^{+}$ETEC produce little or no toxin when grown on most selective media. ${ }^{12}$ Indeed, in our initial evaluation of the kit no isolates produced detectable toxin after culture on MacConkey agar, and only two of 10 isolates (both strongly toxigenic) produced detectable toxin after culture on xylose lysine desoxycholate agar. Evaluation with normal blood agar gave disappointing results, detecting only five of 10 strains. This conflicts with a previously published evaluation of the $\mathrm{COA}^{12}$; one reason for this discrepancy might be the widely differing amounts of toxin produced by strains of $\mathrm{LT}^{+}$ETEC from various geographical locations. ${ }^{2}$ Lincomycin, an inhibitor of protein synthesis, may block production of the enzymes which regulate toxin production in $E$ coli, and can significantly increase the amount of heat labile enterotoxin produced by strains. ${ }^{616}$ Clindamycin, a compound closely related to lincomycin, produces the same effect (Sheffield Public Health Laboratory, unpublished data). The pH of culture media is also important if optimal production of heat labile enterotoxin is to be achieved, heat labile enterotoxin being less readily produced or released from cells at $\mathrm{pH}$ values below neutral. ${ }^{17}$ Combining clindamycin with a raised $\mathrm{pH}$ considerably increased toxin production on blood agar and detected even weakly toxigenic isolates. Using such a modified procedure the kit detected 74 of 87 heat labile enterotoxin plus strains (sensitivity $85 \%$ ) and gave a positive result in only one of 87 heat labile enterotoxin minus strains (specificity $\mathbf{9 8 . 6 \%}$ ).

We conclude that with suitable modifications to the instructions provided with the kit, and to the control and performance of the test, the Phadebact ETEC-LT kit provides a simple, sensitive, and economical method for detecting $\mathrm{LT}^{+}$ETEC. The pronounced increase in foreign travel seen over the past decade seems likely to continue, ${ }^{1819}$ and therefore a rapid screening test for one of the major causes of travellers' diarrhoea is a useful addition to laboratory diagnostic procedures.

We thank Helen Viney and Pharmacia LKB Diagnostics, Pharmacia House, Midsummer Boulevard, Milton Keynes, for providing kits for this work.

\section{References}

1 Guerrant RL. Microbial toxins and diarrhoeal disease: introduction and overview. In: Evered D, Whelan J, eds. Microbial toxins and diarrhoeal disease. Ciba Foundation Symposium No 112. London: Pitman Medical, 1985:1-27.

2 Chapman PA, Mitchelmore DL. A two-year survey of heat-labile enterotoxin-producing Escherichia coli and other enteric pathogens in travellers returning to the Sheffield area. Epidemiol Infect 1988;101:239-47.

3 Echeverria P, Blacklow NR, Smith DH. Role of heat-labile toxigenic Escherichia coli and reovirus-like agent in diarrhoea in Boston children. Lancet 1975;ii:1113-16.

4 Back E, Blomberg T, Wadstrom T. Enterotoxigenic Escherichia coli in Sweden. Infection 1977;5:2-5.

5 Brunton J, Hinde D, Langston C, Gross RJ, Rowe B, Gurwith M. Enterotoxigenic Escherichia coli in central Canada. J Clin Microbiol 1980;11:343-8.

6 Chapman PA, Swift DL. A simplified method for detecting the heat-labile enterotoxin of Escherichia coli. J Med Microbiol 1984;18:399-403.

7 Gross RJ. Escherichia coli diarrhoea. J Infection 1983;7:177-92.

8 Chapman PA. Detection of heat-labile enterotoxin-producing Escherichia coli and their prevalence in acute diarrhoea. [Thesis]. University of Sheffield, 1987;98-104.

9 Guerrant RL, Brunton LL, Schnaitman TC, Rebhun LI, Gilman AG. Cyclic adenosine monophosphate and alteration of chinese hamster ovary cell morphology: a rapid, sensitive in vitro assay for the enterotoxins of Vibrio cholerae and Escherichia coli. Infect Immun 1974;10:320-7.

10 Johnson WM, Lior H. Response of chinese hamster ovary cells to cytolethal distending toxin (CDT) of Escherichia coli and possible misinterpretation as heat-labile enterotoxin. FEMS Microbiol Letts 1987;43:19-23.

11 Sack DA, Huda S, Neogi PKB, Daniel RR, Spira WM. Microtiter ganglioside enzyme-linked immunosorbent assay for Vibrio and Escherichia coli heat-labile enterotoxins and antitoxin. $J$ Clin Microbiol 1980;11:35-40.

12 Ronnberg B, Wadstrom T. Rapid detection by a coagglutination test of heat-labile enterotoxin in cell lysates from blood agargrown Escherichia coli. J Clin Microbiol 1983;17:1021-5.

13 Finkelstein RA, Yang Z. Rapid test for identification of heat-labile 
enterotoxin-producing Escherichia coli colonies. $J$ Clin Microbiol 1983;18:23-8.

14 Bramucci MG, Holmes RK. Radial passive immune haemolysis assay for detection of heat-labile enterotoxin produced by individual colonies of Escherichia colic or Vibrio cholerae. $J$ Clin Microbiol 1978;8:252-5.

15 Honda T, Akhtar Q, Glass RI, Golam Kibriya AKM. A simple assay to detect Escherichia coli producing heat-labile enterotoxin: results of a field study of the Biken test in Bangladesh. Lancet 1981;i:609-10.

16 Levner M, Wiener FP, Rubin BA. Induction of Escherichia coli and Vibrio cholerae enterotoxins by an inhibitor of protein synthesis. Infect Immun 1977;15:132-7.

17 Gilligan PH, Robertson DC. Nutritional requirements for synthesis of heat-labile enterotoxin by enterotoxigenic strains of Escherichia coli. Infect Immun 1979;23:99-107.

18 Business Statistics Office. Business monitor annual statistics. Overseas travel and tourism. London: HMSO, 1985.

19 World Tourism Organisation. Tourism Compendium. Madrid: Graficas Fcc, SL, 1985.

Requests for reprints to: Dr P A Chapman, Public Health Laboratory, Northern General Hospital, Herries Road, Sheffield S5 7AU, England. 